\title{
TE்VŲ, AUGINANČIŲ IKIMOKYKLINIO AMŽIAUS SPECIALIŲJŲ UGDYMOSI POREIKIŲ VAIKUS, PEDAGOGINIS ŠVIETIMAS SIEKIANT PARTNERYSTĖS SU MOKYTOJAIS
}

\author{
Jūraté Klizaitè, lektorè \\ Aniuta Varneckiené, lektoré \\ Aurelija Valaitiené, lektoré \\ Klaipédos valstybine kolegija \\ DOI: https://doi.org/10.52320/svv.v0iVI.193
}

\begin{abstract}
Anotacija
Straipsnyje teoriškai ir praktiškai pagrindžiamas tėvų, auginančių ikimokyklinio amžiaus specialiųjų ugdymosi poreikių vaikus, pedagoginis švietimas bei jo aktualumas, siekiant partnerystès su mokytojais. Tẻvų ir mokytojų bendradarbiavimas, grịstas abipuse partneryste yra reikalingas ir reikšmingas vaikui su specialiaisiais ugdymosi poreikiais, kuris aprèpia suinteresuotus ugdymo dalyvius, galinčius nulemti ugdymo proceso sèkmingumą. Partnerystè - ugdymo dalyviai (tèvai, mokytojai, švietimo pagalbos specialistai ir kt.) yra atviri vieni kitiems, geranoriškai derina savo požiūrius i vaiko ugdymą, tariasi dèl ugdymo tikslų, turinio, vaiko poreikių tenkinimo būdų. Geras bendravimas ir tarpusavio ryšys yra esminis tikros partnerystès bruožas. Tyrimo rezultatai atskleidžia, jog tėvų, auginančių ikimokyklinio amžiaus specialiụju ugdymosi poreikių vaiką, požiūriu, poreikis pedagoginiam švietimui siekiant partnerystès yra aktualus, tačiau labai dažnai jis suprantamas kaip tradicinis jų informavimas apie vaiko ugdymą, o ne bendrų veiklų organizavimas, grịstas dialogiškumu ir refleksija. Labai dažnai vyrauja tradicinès tèvų informavimo formos: bendri susirinkimai, individualūs pokalbiai su grupès pedagogu, informacija pateikiama stenduose.Visiems tèvams priimtiniausios pedagoginio švietimo formos yra individualūs pokalbiai su švietimo pagalbos specialistais ir jų konsultacijos.Tyrimas atskleidè, jog ikimokyklinio ugdymo isstaigoje vyksta nuolatiné tẻvų komunikacija su pedagogais, tačiau jiems dar labai trūksta nuoseklesnès informacijos apie vaiko pasiekimus, vaiko savijautą, reikalingi praktiniai patarimai. Dažiausiai taikomos pedagoginio švietimo formos - individualūs pokalbiai, konsultacijos, kurios padeda suprasti vaiko raidos, ugdymo sunkumus. Poreikis bendradarbiauti, kuris būtų paremtas partneryste yra didžiulis, tačiau tėvai pageidautų iš pedagogų daugiau iniciatyvos.Tik intensyvus bendradarbiavimas ir partnerystè su tėvais gali užtikrinti kokybišką specialiujų ugdymosi poreikių vaikų ugdymą.
\end{abstract}

Pagrindiniai žodžiai: specialiụjų ugdymosi poreikių vaikai, šeima, pedagoginis tėvų švietimas, partnerystė.

\section{Ivadas}

Mokslinė problema. Pastaruoju metu nemažai diskutuojama, jog būtina siekti, kad mokytojai ir tèvai taptų lygiaverčiais ugdymo partneriais, kurie gali nulemti specialiujų ugdymosi poreikių vaikų ugdymo proceso sẻkmingumą bei leistų siekti geriau ịgyvendinti įtraukujjị ugdymą švietimo įstaigose. İtraukusis ugdymas ịgauna platesnę ir daugiamatę prasmę, nes jis siejamas su personalizuotu kiekvieno ugdytinio ugdymu, visų besimokančiųjų ịsitraukimu ị ugdymo procesą, atsižvelgiant ị kiekvieno vaiko poreikius ir galimybes. Ugdymo dalyviai susiduria su nemenkais iššūkiais, kuriuos ne visada pavyksta ivveikti ugdant specialiujų ugdymosi poreikių vaikus. „Vaikas sėkmingai ugdosi, kai namuose, darželyje vadovaujamasi tais pačiais principais: vienodai suprantamas netinkamas elgesys, vienodai $i \mathrm{ji}$ reaguojama, sprendžiamos konfliktinès situacijos bei kt. Ikimokyklinio ugdymo įstaiga, siekdama partnerystės su šeima, turètų kurti ịvairesnes, tèvų ir vaiką atliepiančias, ugdymo ir socialinių paslaugu formas“ (Gustainienè, Širiakovienè, 2020, p. 6).

Galima teigti, jog daugelio autorių darbuose (Braslauskienès, Jonutytès, 2005; Gelžinytès, Bagdono, 2016; Leliūgienès, Simanavičiūtès, 2010; Trakšelio, 2010; Valantino, Čiuladienès; 2012, Kovienès, 2017, Mahmood, 2013;Nihat, Oguz, 2013; Pretis, 2011 ir kt. darbuose), išskiriama pedagoginio švietimo samprata, kurios tikslas yra sėkminga vaiko socializacija, pagalbos šeimai būtinumas ugdant agresyvius vaikus, tèvų įtraukimas, siekant aktyvaus jų dalyvavimo ugdomojoje veikloje bei siekiant ugdymo tęstinumo namuose. Kita vertus, organizuotas pedagoginis tėvų švietimas dažnai būna trumpalaikis ir nenuoseklus. Atsakingai ì vaikų ugdymą žiūrintys tèvai, norèdami konstruktyviai dalyvauti švietimo veikloje, turi patys tam pasirengti, igyti reikiamą pedagoginę ir kultūrinę kompetenciją (Kovienė, 2017). Savo tyrimais (Kovienė, 2018; Čiuladienė, Valantinas, 2016) atskleidè pagrindines pedagogų ir tèvų partnerystès problemas: netikslingi, reti tėvų pedagogų susitikimai; prastas tėvų požiūris ị ugdymo ịstaigą; pedagogus; tėvų nesugebėjimas ar nenoras auklèti 
savo vaikų; tèvų pedagoginès kultūros stoka; tèvų ir pedagogų reikalavimų vieni kitiems nesuderinimas; grupès tèvų bendruomenès nebuvimas arba pasyvi jos veikla; neįvairinamos bendradarbiavimo su tèvais formos (cit.Gustainiené, Širiakoviené, 2020, p. 8). Tiek teoriniu, tiek empiriniu aspektais, kaip tėvų, auginančių ikimokyklinio amžiaus specialiųų ugdymosi poreikių vaikus, vyksta pedagoginis švietimas, siekiant partnerystès su mokytojais, ši tema nèra pakankamai išplètota. Pastebima tendencija, jog pedagogai, dirbantys su specialiųjų ugdymosi poreikių vaikais, ne visada orientuojasi $\mathfrak{i}$ jų tėvus, kaip $\mathfrak{i}$ partnerius, netaiko reikšmingų tai grupei bendradarbiavimo formų, tuo patys susiaurina tėvų dalyvavimą ugdymo procese, bendradarbiavimo galimybes ir jo efektyvumą. Kyla tyrimo problemą suponuojantis klausimas: kaip vyksta tèvu, auginančiu ikimokyklinio amžiaus specialiuju ugdymosi poreikiu vaikus, pedagoginis švietimas siekiant partnerystès su mokytojais?

Tyrimo objektas - pedagoginis tėvų švietimas siekiant partnerystès su mokytojais.

Tyrimo tikslas - išanalizuoti tėvų, auginančių ikimokyklinio amžiaus specialiujų ugdymosi poreikių vaikus, pedagoginị švietimą siekiant partnerystès su mokytojais.

\section{Tyrimo uždaviniai:}

1. Teorinès analizès būdu atskleisti tėvų, auginančių ikimokyklinio amžiaus specialiųjų ugdymosi poreikių vaikus, pedagoginį švietimą siekiant partnerystės su mokytojais.

2. Nustatyti kylančias problemas ir sunkumus ịvertinant ikimokyklinio amžiaus specialiujų ugdymosi poreikių vaikų tèvų pedagoginị švietimą siekiant partnerystès su mokytojais.

Tyrimo metodai: 1) mokslinès literatūros analizè, 2) apklausa žodžiu, naudojant pusiau struktūrizuotą interviu. Duomenys apdoroti taikant kokybinio turinio analizę.

Tyrimo etapai: 1) mokslinès literatūros analizè. Atrinkti mokslinès literatūros leidiniai, straipsniai, kurie buvo nagrinèjami išskiriant tyrimo objektą, tikslą, problemini klausimą. Nuosekli literatūros paieška buvo atlikta EBSCOhost duomenų bazèje. Raktiniai žodžiai - pedagoginis tėvų švietimas, ikimokyklinio amžiaus vaikų specialieji ugdymosi poreikiai, partnerystè buvo naudojami atliekant išplèstinę paiešką; 2) interviu klausimų kūrimas; 3) apklausa žodžiu; 4) gautų duomenų analizavimas.

Tyrimo etika. Atliekant tyrimą buvo laikomasi tyrimo etikos principų. Visi tyrimo dalyviai buvo informuoti apie tyrimo tikslą, konfidencialumą. Tyrimo rezultatai nèra reprezentatyvūs, bet padeda pastebèti tam tikras aktualias tendencijas.

\section{Tèvų, auginančių ikimokyklinio amžiaus specialiųjų ugdymosi poreikių vaikus, pedagoginio švietimo, siekiant partnerystès su mokytojais, teorinès prielaidos}

Plètojantis tèvų teisèms ir pareigoms atsiranda būtinumas jiems gauti kvalifikuotą pagalbą vaikų ugdymo klausimais. Pastaruoju metu bendrojo ugdymo ịstaigas lanko specialiujų ugdymosi poreikių vaikai, turėdami įvairių raidos sutrikimų, kurie lemia ugdymosi sunkumus. Tai ịpareigoja tiek ugdymo įstaigą, tiek tèvus tapti dviem nuolatos sąveikaujančiomis bei viena kitą papildančiomis institucijomis, leidžiančioms sėkmingai igyvendinti ugdymo tikslus. Labai svarbus tampa šių ugdymo dalyvių glaudus ryšys, kuris gali duoti teigiamų pokyčių specialiųų ugdymosi poreikių vaiko ugdymui, asmenybès formavimui. Šiandien ugdymo įstaigos labiau turètų eiti nuo abipusio atvirumo ir keitimosi informacija santykio link dialogu grịstos partnerystès su tèvais, o tèvai taip pat siektu su mokytojais geranoriškai derinti savo požiūrius ị vaiko ugdymą, tartųsi dẻl vaiko poreikių tenkinimo įvairesnių formų, būdų vaiko gerovès labui.

Šiandien yra siektina, jog mokytojai ir tėvai taptų lygiaverčiais ugdymo partneriais. Tèvai susiduria su naujais socialiniais reiškiniais, dažnai jaučiasi sutrikę, nes ne visada geba, nori prisitaikyti prie sparčiai kintančios aplinkos, nesuvokia, kokią ịtaką jie gali daryti vaiko ugdymosi pasiekimams ir pažangai. Tẻvų pedagoginis švietimas yra suprantamas ne vien informacijos teikimas, bet ir reikiamų igūdžių formavimas per ugdymo ịstaigos ir tėvų bendradarbiavimą (Kovienè, 2017).

Atlikta mokslinių šaltinių ( Gustainienès, Širiakovienès, 2020; Burvytės, 2013; Kovienès, 2017; Martišauskinès, Trakšelio, 2017; Valantino, Čiuladienès, 2013 ir kt) analizè leidžia teigti, jog tėvų švietimas turi būti suprantamas ne kaip jų informavimas.Vyrauja tradicinès tèvų informavimo formos: 
bendri susirinkimai, individualūs pokalbiai su grupès pedagogu, informacija pateikiama stenduose. Pedagogai, dirbantys su specialiųjų ugdymosi poreikių vaikais, elgesio sunkumų turinčiais vaikais, ne visada orientuojasi ị tèvus kaip partnerius, kartais siūlo tik nereikšmingas bendradarbiavimo sritis, taip susiaurindami tẻvų dalyvavimą, bendradarbiaavimo galimybes ir jo efektyvumą. Tévai ir pedagogai dažniausiai bendrauja pokalbių metu, kai atvedami arba pasiimami vaikai. Trumpalaikis bendravimas ne visada užtikrina pakankamai individualų demesi kiekvieno vaiko ugdymo pasiekimų aptarimui (Gustainienè, Širiakovienè, 2020). Galima teigti, jog tèvai tokị reiškinị identifikuoja kaip tradicinị informacijos apie vaikų ugdymą gavimą, nes kartais tai vyksta kaip žinių gausinimas. Pasak Burvytės (2013), „tokios bendradarbiavimo sritys kaip analizè, ịsivertinimas ir bendrų veiklų organizavimas, grịstas dialogiškumu ir refleksija, yra mažiausiai igyvendinamos" (p. 23). Dialogas yra geriausia susikalbẻjimo, sutarimo ir susitarimo bei konfliktų sprendimo forma. Šiandien tèvai jaučia poreikị plèsti savo žinias, susijusias su vaiko ugdymu, suvokia pedagoginio švietimo reikšmę partnerystès su mokytojais kokybės gerinimui. Tẻvai norètų diskusijų, kurių metu galètų pasidalinti savo patirtimi, jie labiau norètų dalyvauti vaiko grupès veikloje, labiau užsièmimų su praktiniais pavyzdžiais, inovacijų, labiau įtraukiančių tėvus ir atliepiančių tam tikras tendencijas (nufilmuota vykusi paskaita, įdomi veikla ir kt.) (Kovienè, 2017). Labai svarbu igalinti įvairialypi bendradarbiavimą, o dialogas labai svarbus numatant bendradarbiavimo galimybes ugdant specialiujų ugdymosi poreikių vaikus, pritaikant ugdymo turinį, metodus, kuriant sąveiką tarp šeimos ir mokytojo.

\section{Tyrimo metodologija}

Tyrimas atliktas $2021 \mathrm{~m}$. sausio - birželio mėn. Norint atskleisti, tėvų, auginančių ikimokyklinio amžiaus specialiujų ugdymosi poreikių vaikus, pedagoginị švietimą, siekant partnerystès su mokytojais, pasirinkti mokslinès literatūros analizès bei kokybiniai tyrimo metodai - pusiau struktūrizuotas interviu ir kokybinio turinio analizè. Tyrimo dalyviais pasirinkti 5 tèvai, kurių vaikai yra su specialiaisiais ugdymosi poreikiais. Tiriamieji buvo suskirstyti ị grupes pagal amžių: (nuo 31 iki 34 metų); pagal amžiaus skirsnị, tyrime dalyvavo moterys. Gauti rezultatai atskleidè, kad pusė apklausoje dalyvavusių tèvų turi aukštaji universitetinị ir neuniversitetinị išsilavinimą, du informantai vidurinį. Šie demografiniai duomenys leidžia teigti, jog informantai galètų tinkamai vertinti pateiktus klausimus ir ị juos atsakyti. Interviu su tėvų, auginančių ikimokyklinio amžiaus specialiụjų ugdymosi poreikių vaikus, gauta medžiaga analizuota indukciniu būdu išskiriant prasminius vienetus, juos formuluojant i subkategorijas, jungiant i kategorijas, kurios iliustruotos informantų citatomis. Kategorijos: specialiųjų ugdymosi poreikių vaikų ugdymo problemos ir jų sprendimo būdai, tẻvų pedagoginio švietimo formos, aktualiausios temos siekiant partnerystès su mokytojais: Kokie tèvams dažniausiai kyla klausimai, kurie susiję su vaiko ugdymu? Su kuo bei kaip dažniausiai tèvai sprendžia iškilusias vaiko ugdymo problemas? Kodèl? Klausimai apie priimtiniausias tèvu pedagoginio švietimo formas, siekiant partnerystès su mokytojais?Kokios tèvams priimtiniausios pedagoginio švietimo formos padeda labiau jiems suprasti vaiko specialiuosius ugdymosi poreikius bei ju galimybę dalyvauti ugdymo procese? Kodèl jie taip mano? Klausimai apie pedagogų siūlomas temas, pagalbą bei lūkesčius iš ugdymo dalyvių: Kokios tèvams dažniausiai siūlomos pedagogu temos specialiuju ugdymosi poreikio vaiko ugdymo klausimais ikimokyklinio ugdymo istaigoje? Kokiomis temomis tèvai norètu pagilinti savo žinias, susijusias su vaiko ugdymu?Kodèl? Ko tikëjosi tèvai (kokios pagalbos, žiniu ir pan.) iš ugdymo ịstaigoje dirbančiu pedagogu ir kt. bei kokia pagalba jiems buvo suteikta? Ar patys tèvai rodo iniciatyva, užmegzdami bendradarbiavimo santykius su ikimokyklinio ugdymo ìstaiga, gal norètu didesnès iniciatyvos iš pedagogu pusès?

Irašant interviu naudota garso įrašymo priemonè. Garso įrašas stenografuotas bei taikyta kokybinio turinio analizè.

\section{Tyrimo rezultatai}

Geras bendravimas ir tarpusavio ryšys yra esminis tikros partnerystės bruožas. Bendravimas padeda žmonėms geriau suprasti vieniems kitus, ịsigilinti ị kito vidini pasaulị, skatina išklausyti kito 
nuomonę bei išsakyti savo. Mokytojai, kurie suvokia šeimos svarbą ugdant specialiujų ugdymosi poreikių vaikus, ir tiki, kad dirbdami su tèvais, gali daug pasiekti, gali sukurti tikrą partnerystę. Tèvų ir mokytojų nuostatos ị bendravimą ir bendradarbiavimą skiriasi. Dauguma tévų mano, jog tik pedagogai turi rodyti iniciatyvą kuriant partneriškus santykius, pedagogai didesnès iniciatyvos tikisi iš tėvų. Ikimokykliniame amžiuje tèvai yra patys svarbiausi ugdymo proceso dalyviai, kur tikra partneryste yra reikalingiausia.

Šiuo interviu klausimu buvo siekiama išsiaiškinti, kokios dažniausiai tėvams, auginantiems ikimokyklinio amžiaus specialiųų ugdymosi poreikių vaiką, iškyla ugdymo problemos ir taikomi ju sprendimo būdai švietimo ìstaigoje, pateikta 1 lentelèje.

1 lentelè. Te்vų nuomonès pasiskirstymas apie iškylančius vaiko ugdymo problemas ir jų sprendimo būdus

\begin{tabular}{|c|c|c|}
\hline Kategorija & Subkategorijos & İrodantys teiginiai \\
\hline \multirow{4}{*}{$\begin{array}{l}\text { Klausimai, susiję } \\
\text { su vaiko ugdymo } \\
\text { problemomis ir jų } \\
\text { sprendimo būdais }\end{array}$} & $\begin{array}{l}\text { Bendravimo ir } \\
\text { elgesio problemos }\end{array}$ & $\begin{array}{l}\text { „Man labai svabios mano vaiko elgesio problemos, kalba, jo mokejimas } \\
\text { pasakyti, o taip pat labai svarbus, socialinis bendravimas su vaikais. "(A) } \\
\text { „Kaip sekasi bendrauti, ar reikalinga pedagogu pagalba, kur reikèty } \\
\text { pasitempti.“(D) }\end{array}$ \\
\hline & $\begin{array}{l}\text { Švietimo pagalbos } \\
\text { specialistų } \\
\text { siūlomi būdai }\end{array}$ & 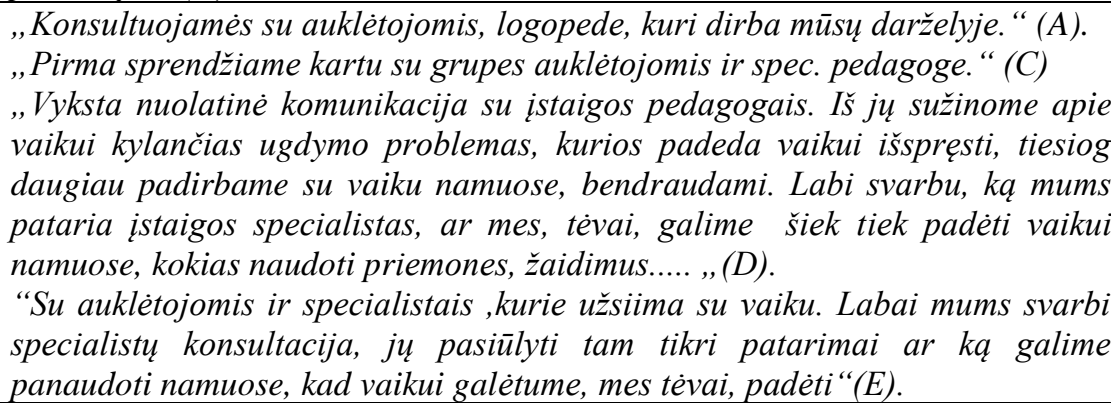 \\
\hline & $\begin{array}{l}\text { Klausimai, susiję } \\
\text { su vaiko pažanga } \\
\text { ir pasiekimais }\end{array}$ & $\begin{array}{l}\text { „Kaip vaikui sekèsi ta diena (kasdien aktualu) ar kažkas sekèsi geriau, } \\
\text { pastebèjo darant pažanga, ar kaip tik, blogèja situacija, nevykdo prašymu, } \\
\text { neatlieka užduočiu.(A),, Kaip padėti vaikui tobulèti, kokius metodus taikyti. } \\
\text { Koks turètu būti eiliškumas “(B),(E). } \\
\text { „Elementarūs: kaip vaikui sekasi atlikti užduotis.i Namuose, didžiausias } \\
\text { klausimas, kaip motyvuoti vaika atlikti ịvairias užduotis, kaip ugdyti didesni } \\
\text { savarankiškuma, pareigos jausma ,,(D). }\end{array}$ \\
\hline & $\begin{array}{l}\text { Literatūros } \\
\text { šaltinių } \\
\text { studijavimas bei } \\
\text { kiti būdai }\end{array}$ & $\begin{array}{l}\text { „Skaitau psichologine literatūra „,lietaus vaikai,, ir taip pat } \\
\text { internete. “,Skaitome pedagoginę, psichologinę literatūra, straipsnius } \\
\text { interneto platybèse, dalyvaujame seminaruose. “( D) } \\
\text { „Skaitau papildoma literatūra, bendrauju su tèvais kurie susiduria su } \\
\text { panašiais sunkumais. Taip pat lankome papildomai ergoterapijos, logopedo } \\
\text { užsiemimus, sanatorijas ir t.t. Tiesiog po truputi iš visur susirenku } \\
\text { informacija“ (B). }\end{array}$ \\
\hline
\end{tabular}

Šaltinis: sudaryta pagal autorių atlikto tyrimo duomenis, $2021 \mathrm{~m}$.

Analizuojant informantų nuomonę paaiškejjo (1 lentelè), jog kai kuriems tėvams, auginantiems specialiųjų ugdymosi poreikių vaiką, jokių klausimų nekyla. ,...didesniu, rimtesniu klausimu nekyla, pasitikime istaiga, jos pedagogais, komunikuojame su jais, tad žinome, kad vaikas gauna visa reikalinga pagalba“. Tyrimas atskleidè, kad daugumai informantų (A),(B),(D),(E), rūpi, klausimai apie ugdymosi pažangą ir pasiekimus, kaip vaikui sekasi atlikti užduotis, ar pastebejjus darant pažangą.“.." kaip vaikui sekèsi ta diena (kasdien aktualu) ar kažkas sekèsi geriau, pastebejjo darant pažanga, ar kaip tik, blogëja situacija, nevykdo prašymu, neatlieka užduočiu“", ,...,,kaip sekasi vaikui tobuleti". Tèvams labai svarbi ịvairi informacija bendravimo klausimais (C), (D). “... kaip sekasi bendrauti, ar reikalinga pedagogu pagalba, kur reikètu pasitempti. “ Apibendrinant galima teigti, jog tèvai domisi vaiko pažanga ir pasiekimais, bendravimu su bendraamžiais, kas igalina mokytojus, švietimo pagalbos specialistus savo žiniomis, patirtimi visapusiškai padèti tèvams suprasti vaiko raidą bei jo galimybes ir pastebimus ugdymo sunkumus. Informantų vertinimu, daugiausia jie iškilusias vaiko ugdymo problemas sprendžia su švietimo pagalbos specialistais, bet labai svarbūs yra mokytojo patarimai. Kiti informacijos ieško internetinèse svetainèse, skaito specialią literatūrą, bendrauja su 
kitais tèvais, kurie susiduria su panašiais sunkumais, lanko papildomus užsièmimus, konsultuojasi. Tèvai supranta, jog svarbi yra tiesioginė specialistų pagalba ugdymo procese. Gauti tyrimo duomenys (1 lentelè) rodo, kad tèvai gerai supranta pagalbos svarbą švietimo ịstaigoje, nes išskiria tiek mokytojo, tiek švietimo pagalbos specialistų svarbą sprendžiant iškilusius klausimus, kurie susiję su vaiko ugdymu. Tai leidžia teigti, kad teisingas specialiuju ugdymosi poreikių vaikų tèvų supratimas apie pagalbos specialistų švietimo įstaigoje veiklą, bendradarbiavimo svarbą su kitais ugdymo dalyviais, igalina juos nuolat palaikyti glaudžius tarpusavio ryšius, ugdant specialiųų ugdymosi poreikių vaiką.

Kaip tèvai apibūdina priimtiniausias pedagoginio švietimo formas, atskleidžia 2 lentelè.

2 lentelè. Tèvų nuomonès pasiskirstymas apie priimtiniausias pedagoginio švietimo formas

\begin{tabular}{|c|c|c|}
\hline Kategorija & Subkategorijos & Irodantys teiginiai \\
\hline \multirow{3}{*}{$\begin{array}{l}\text { Priimtiniausios } \\
\text { pedagoginio } \\
\text { švietimo formos }\end{array}$} & Konsultacijos & 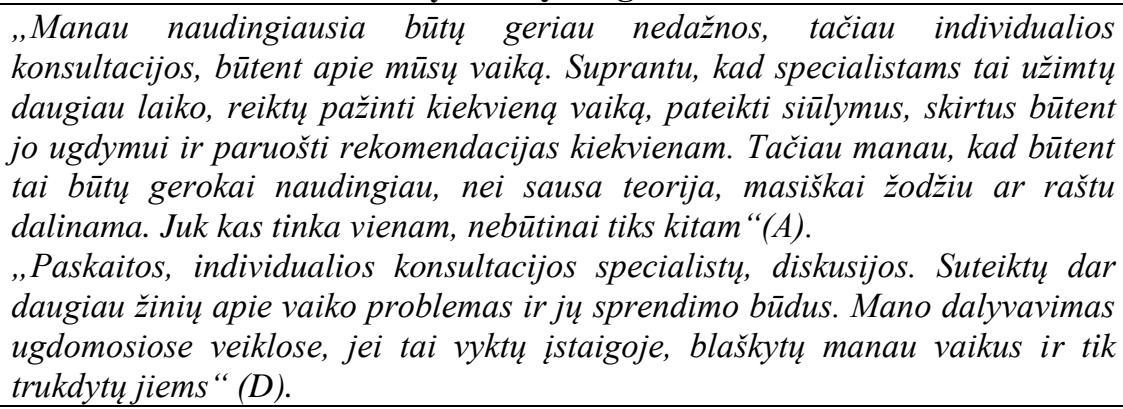 \\
\hline & $\begin{array}{l}\text { Individualūs } \\
\text { pokalbiai }\end{array}$ & $\begin{array}{l}\text { „Bendros edukacinès veiklos, paskaitos, individualūs pokalbiai. Kodèl taip } \\
\text { manau? Nes bendradarbiaujant galime greičiau pasiekti rezultatu“ (B). } \\
\text { „Paskaitos, individualios konsultacijos specialistu, diskusijos. Suteiktu dar } \\
\text { daugiau žiniu apie vaiko problemas ir ju sprendimo büdus. Mano dalyvavimas } \\
\text { ugdomosiose veiklose, jei tai vyktu ìstaigoje, blaškytu manau vaikus ir tik } \\
\text { trukdytu jiems. “(D) }\end{array}$ \\
\hline & $\begin{array}{c}\text { Dalyvavimas } \\
\text { ugdomosiose } \\
\text { veiklose }\end{array}$ & $\begin{array}{l}\text { „Neformali veikla, kai vaikas gali labiau nevaržyti savęs ir tada labiau bus } \\
\text { linkęs bendrauti ir dirbti kartu. “(C) } \\
\text { „Mano dalyvavimas ugdomosiose veiklose, jei tai vyktu istaigoje, blaškytu } \\
\text { manau vaikus ir tik trukdytu jiems, bet tai bütu ir labai svarbu man, pamatyti } \\
\text { savo vaika veiklose. “(D) } \\
\text { „Bendros edukacinès veiklos, paskaitos, individualūs pokalbiai. Kodèl taip } \\
\text { manau? Nes bendradarbiaujant galime greičiau pasiekti rezultatu, norisi } \\
\text { daugiau aktyviu veiklu. To labiausiai norèčiau.“(B) } \\
\text { „Visos, kurios padètu. “(E) }\end{array}$ \\
\hline
\end{tabular}

Šaltinis: sudaryta pagal autorių atlikto tyrimo duomenis, $2021 \mathrm{~m}$.

Gauti tyrimo duomenys atskleidè, kad tėvams priimtiniausios pedagoginio švietimo formos: individualūs pokalbiai, diskusijos, pageidautų aktyvių veiklų, kuriose jie būtų įtraukiami. Labai svarbi ikimokyklinio ugdymo ịstaigoje tėvams teikiama specialiojo pedagogo, logopedo individuali konsultacija, aktyvus dalyvavimas tèvų ugdomosiose veiklose, bet „ne sausa teorija. “ Tai labiausiai padeda tėvams suprasti vaiko specialiuosius ugdymosi poreikius. Vieno informanto teigimu, ,...visos, kurios padètu“. Kasdieninis ir nuolatinis tèvų, mokytojų ir švietimo pagalbos specialistų bendradarbiavimas, sklandus informacijos valdymas yra pagrindinès kokybiško ir sèkmingo vaiko su specialiaisiais ugdymosi poreikiais ugdymo sąlygos, kai siekiama teigiamų jo augimo, tobulëjimo, ugdymosi pokyčių ir progreso. Formų ivvairovè ir tinkamas jų panaudojimas leidžia tėvams ir pedagogams būti aktyviais bendradarbiavimo partneriais (Martišauskienè, 2008). Galima teigti, jog tèvai, auginantys ikimokyklinio amžiaus specialiujų ugdymosi poreikių vaikus, labiau pageidauja aktyvių, bendrų edukacinių veiklų, kuriose jie būtų įtraukiami kartu su vaiku. Tokios aktyvios veiklos, leistų tėvams labiau pastebėti vaiko galias ir sunkumus, siekti ugdymo tęstinumo namuose.

Kaip tèvai pasisako apie siūlomas temas vaiko ugdymosi klausimais švietimo ìstaigoje, pateikta 3 lentelèje. 
3 lentelè. Tẻvų nuomonès pasiskirstymas apie siūlomas temas švietimo įstaigoje

\begin{tabular}{|c|c|c|}
\hline Kategorija & Subkategorijos & İrodantys teiginiai \\
\hline \multirow{3}{*}{$\begin{array}{c}\text { Tèvams siūlomos } \\
\text { temos }\end{array}$} & $\begin{array}{l}\text { Bendravimo } \\
\text { klausimais }\end{array}$ & $\begin{array}{l}\text { „Auklètoja pasiūlè susitikti ir pabendrauti vaiko bendravimo klausimais, bet } \\
\text { tai nebūna dažnai. Daugiau informacija teikia specialistai“(C), E). } \\
\text { „Buvo pasiūlyta pasikalbèti apie vaiku bendravima su bendraamžiais, kur } \\
\text { daugiausia kyla problemu, kai vaikas nenori bendrauti, jam geriau žaisti } \\
\text { vienam, kartais ir kiti vaikai nenori jo priimti i žaidimus“(B). }\end{array}$ \\
\hline & $\begin{array}{l}\text { Socialinių ịūdžių } \\
\text { formavimo } \\
\text { klausimais }\end{array}$ & $\begin{array}{l}\text { Kartais auklètojos siūlo pabendrauti dèl vaiku socialiniu igūdžiu formavimo, } \\
\text { tai labiau susiję su vaiko bendravimu, kuris pastebimas su kitais } \\
\text { vaikais“(A). } \\
\text { „Socialiniu igūdžiu formavimo, konfliktu sprendimo klausimais“(D). }\end{array}$ \\
\hline & $\begin{array}{l}\text { Vaiko elgesio ir } \\
\text { konfliktų } \\
\text { sprendimo } \\
\text { klausimais }\end{array}$ & $\begin{array}{l}\text { Paskutinès, kurias pamenu, vaiko elgesio ir konfliktu sprendimo klausimais, } \\
\text { kuriose buvo tam tikru patarimu“ (A). } \\
\text { „konfliktu sprendimo klausimais, kurie dažnai büna ne tik su grupès vaikais, } \\
\text { bet ir namuose“(D). }\end{array}$ \\
\hline
\end{tabular}

Šaltinis: sudaryta pagal autorių atlikto tyrimo duomenis, $2021 \mathrm{~m}$.

Analizuojant gautus tyrimo duomenis pastebėta, jog svarbiausios temos tėvams yra: vaiku bendravimo ypatumai, socialinių ịgūdžių formavimas, konfliktų sprendimo būdai, kurios labiausiai padeda atskleisti problemas bendraujant su bendraamžiais, mokytojais, laisvalaikiu bei ugdomosiose veiklose. Visi tèvai (A, D, C,D,E) teigia, kad tokios siūlomos temos yra pačios svarbiausios ir turi itakos vaiko su specialiaisiais ugdymosi poreikiais pasiekimams. Tẻvų nuomone, „...žinios apie tinkamo bendravimo ypatumus leidžia jiems suprasti vaiko raidos ypatumus, skatina pozityvesni tarpusavio bendravima ir bendradarbiavima, padeda vaikui lengviau prisitaikyti ugdymo istaigoje, jaustis svarbiu bei reikšmingu, geriau sutarti su bendraamžiais." Kita vertus, galima sutikti su teiginiu, jog bendradarbiavimas su švietimo įstaiga labiau suaktyvèja, jeigu iškyla vaiko elgesio problemų, suprastejjus ugdymo pasiekimams. Labai svarbu ịgalinti ịvairiakryptị bendradarbiavimą, kuris leistų atliepti ịvairesnių temų poreikị tėvams bei labiau sustiprintų tėvų partnerystę su mokytojais sprendžiant vaiko ugdymo problemas.

Kaip interviu dalyviai apibūdina temas, kurios pagilintu ju žinias apie vaiko ugdymąsi, pateikta 4 lenteleje.

4 lentelè Tẻvų nuomonès pasikrtymas apie dažniausiai siūlomas temas, kurios pagilintų jų žinias apie vaiko ugdymąsi

\begin{tabular}{|c|c|c|}
\hline Kategorija & Subkategorijos & İrodantys teiginiai \\
\hline \multirow{3}{*}{$\begin{array}{c}\text { Dažniausiai } \\
\text { siūlomos temos, } \\
\text { kurios pagilintu } \\
\text { tėvų žinias apie } \\
\text { vaiko ugdymąsi }\end{array}$} & Elgesio sunkumai & $\begin{array}{l}\text { „Elgesys su bendraamžiais ir suaugusiais, deramo elgesio formavimas, kuris } \\
\text { palengvintu vaiko bendravima, tobulintu bendravimo gebejjimus“ (A). } \\
\text { „Gero elgesio formavimas, konfliktu sprendimas, kuris būna su tèvais, su } \\
\text { auklètoja, su kitais vaikais. Kaip reikètu elgtis tam tikrais atvejais “ (B). } \\
\text { „Elgesys su bendraamžiais, kodèl sunku vaikui dalintis žaislais su kitais } \\
\text { vaikais, nes tai lemia jo elgesĭ, kontroliuoti elgesĭ, jeigu kažkas nepatinka“ (C). }\end{array}$ \\
\hline & $\begin{array}{l}\text { Bendravimo } \\
\text { ypatumai }\end{array}$ & 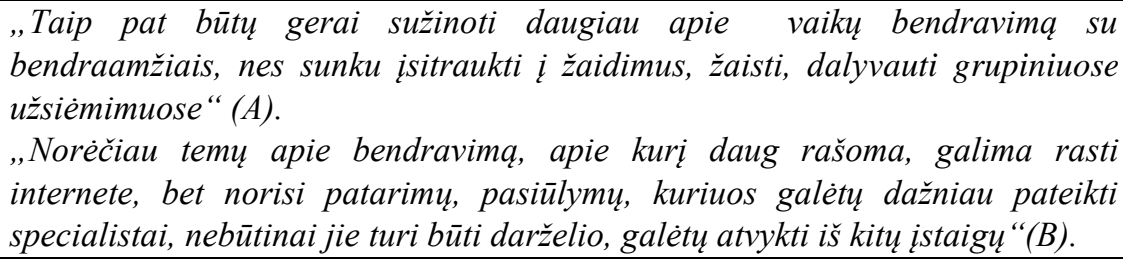 \\
\hline & $\begin{array}{l}\text { Kalbinių } \\
\text { gebejjimų } \\
\text { ugdymas }\end{array}$ & $\begin{array}{l}\text { „Noréčiau išgirsti, kaip lavinti vaiko kalbèjima, kokius pratimus, užduotis } \\
\text { galime atlikti kartu su vaiku. Tai galbūt leistu labiau tobulinti vaiko kalba } \\
\text { Viskas, kas susiję su kalbos lavinimu ir raida“(C). } \\
\text { „Man labiausiai rūpi temos vaiko kalbos formavimo klausimais, nes vaikas turi } \\
\text { sunkumu su kalba, o tai apsunkina jo bendravima su kitais vaikais, su } \\
\text { suaugusiais, kaip lavinti vaiko kalbèjima, kaip atpažinti vaiko raidos } \\
\text { ypatumus, ju gebejimus.,,(D). }\end{array}$ \\
\hline
\end{tabular}

Šaltinis: sudaryta pagal autorių atlikto tyrimo duomenis, $2021 \mathrm{~m}$.

Analizuojant gautus duomenis pastebèta (4 lentelè), jog informantų atsakymai pasiskirste $i$ tris grupes. Vieni nori daugiau sužinoti apie vaiko emocijų valdymą ir elgesio sunkumus, kiti apie vaikų 
bendravimą su bendraamžiais. Taip pat tėvams svarbi tema vaiko kalbinių gebėjimų klausimais. Specialiujų ugdymosi poreikių vaikų tėvus baugina mintis, ar jų vaikas gebės suprasti bei dalyvauti ugdomosiose veiklose taip pat kaip kiti grupès vaikais, draugauti su bendraamžiais, ar nebus pamirštas, ypatingai ugdymo procese. Tévams svarbu, ar jų vaikas taps pakankamai savarankiška asmenybe. Apklausa atskleidè, kad tèvams nepakanka pedagoginių-psichologinių žinių apie jų vaiko specialiuosius ugdymosi poreikius ir ugdymą. Su kokiais sunkumais susiduria tèvai, siekdami gauti išsamesnès informacijos apie vaiko poreikius, ugdymo ypatumus iš pedagogų ar kitų švietimo pagalbos specialistų? Interviu tyrimo duomenų analizè atskleidè, kad tėvai (A), (B), (C),(D), (E) nesusiduria su sunkumais „...nesusiduriame, visada gauname atsakymus $i$ visus rüpimus klausimus", “...jokiu sunkumu“. Kai kuriems tèvams trūksta laiko ,...kokybiškam pokalbiui reikia skirti laiko. „,...manau asmeniniai ir bendri susirinkimai labai padètu“.

Ko tikejosi tèvai (kokios pagalbos, žiniu ir pan.) iš ugdymo ìstaigos administracijos ir joje dirbančiu pedagogu bei švietimo pagalbos specialistu, kokia pagalba jiems ir vaikui suteike ugdymo istaigos darbuotojai pateikta 5 lenteleje.

5 lentelè. Tẻvų nuomonès pasiskirstymas apie lūkesčius dèl pagalbos iš ugdymo įstaigos

\begin{tabular}{|c|c|c|}
\hline Kategorija & Subkategorijos & İrodantys teiginiai \\
\hline \multirow[t]{2}{*}{$\begin{array}{l}\text { Tèvų lūkesčiai } \\
\text { dèl teikiamos } \\
\text { pagalbos švietimo } \\
\text { įstaigoje }\end{array}$} & $\begin{array}{l}\text { Ugdymo dalyvių } \\
\text { pagalba }\end{array}$ & 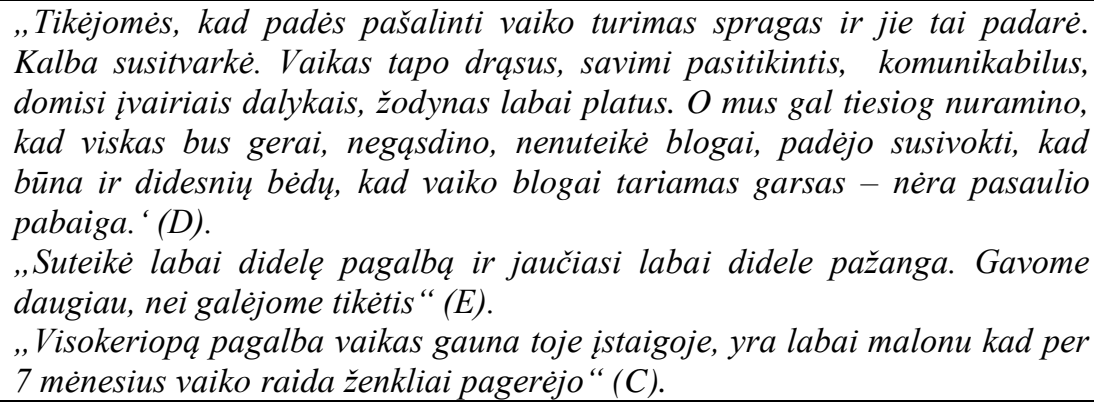 \\
\hline & Specialistu pagalba & $\begin{array}{l}\text { „Specialistai suteikia visokeriopa pagalba. Gavome ir gauname daugiau, nei } \\
\text { galejome tiketis. Esame labai jiems dekingi“ (E). } \\
\text { "Tikejausi logoterapeuto paslaugu“ }(B) \text {. }\end{array}$ \\
\hline
\end{tabular}

Šaltinis: sudaryta pagal autorių atlikto tyrimo duomenis, $2021 \mathrm{~m}$.

Gauti tyrimo duomenys atskleidè, kad tèvai gavo pagalbos iš ugdymo ịstaigos, net daugiau nei tikèjosi,„...specialistai suteikia visokeriopa pagalba. Gavome ir gauname daugiau, nei galëjome tikètis. Esame labai jiems dékingi“"“... juvariapuse pagalba vaikas gauna toje istaigoje, yra labai malonu kad per 7 ménesius vaiko raida ženkliai pagèèjo " Tèvai džiaugiasi, kad švietimo ìstaigos logopedai padeda koreguoti vaiko kalbos ir kalbejjimo turimas sutrikimus. „Vaikas tampa drasesnis, labiau pasitikintis savimi." Tai tèvus nuteikia pozityviam bendravimui ir bendradarbiavimui su ugdymo dalyviais.

Kokios pagalbos ikimokyklinio ugdymo isstaiga nesuteike, kokios pagalbos, žiniu ir pan. norètu gauti apie ju vaiko ugdymo ypatumus bei poreikius, pedagogini švietima iš ugdymo istaigoje dirbančiu: administracijos atstovu, pedagogu ar švietimo pagalbos specialistu, pateikta 6 lenteleje. Interviu metu paaiškèjo, tèvai norètų, kad ikimokyklinio ugdymo ịstaigoje būtų ịvairių specialistų, kurie galètų jų vaikams suteikti reikiamą pagalbą: kaip ergoterapijos, kinezioterapijos specialistų. Smulkiosios motorikos lavinimui, judesio-sensorikos lavinimui, daugiau valandų ugdymui būtų skirta specialiajam pedagogui, psichologui, logopedui. Iš ikimokyklinio ugdymo ịstaigos dirbančiu administracijos atstovų, pedagogų ar švietimo pagalbos specialistų gauna atsakymus $\mathfrak{i}$ visus pateiktus klausimus. “... $i$ visus klausimus gauname atsakymus, reikia tik klausti“(D). ,...gavome visa pagalba“" $(E)$. 
6 lentelè. Tẻvų nuomonės pasiskirstymas apie nesuteiktą bei norimą pagalbą ikimokyklinio ugdymo istaigoje

\begin{tabular}{|c|c|c|}
\hline Kategorija & Subkategorijos & İrodantys teiginiai \\
\hline \multirow[t]{3}{*}{$\begin{array}{c}\text { Tèvų nuomonės } \\
\text { pasiskirstymas } \\
\text { apie nesuteiktą } \\
\text { bei norimą } \\
\text { pagalbą }\end{array}$} & $\begin{array}{l}\text { Specialistuc } \\
\text { pagalba }\end{array}$ & 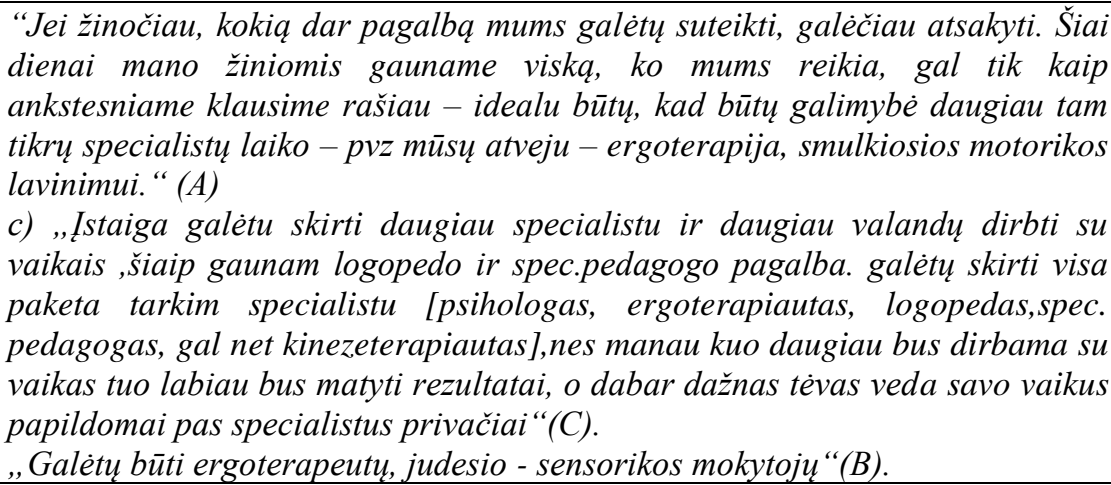 \\
\hline & Metodinès žinios & $\begin{array}{l}\text { "Norètųsi žinoti kokios metodikos taikomos ir kaip konkrečiai naudojamos. } \\
\text { Norètųsi aktyviau dalyvauti lavinime, pritaikyti ta patị namuose" (B). }\end{array}$ \\
\hline & Suteikta pagalba & $\begin{array}{l}\text { „I visus klausimus gauname atsakymus, reikia tik klausti.“(D) } \\
\text { „Gavome visa pagalba“ }(\text { E). }\end{array}$ \\
\hline
\end{tabular}

Šaltinis: sudaryta pagal autorių atlikto tyrimo duomenis, $2021 \mathrm{~m}$.

Buvo pasidomèta, ar patys tèvai rodo iniciatyva, užmegzdami bendradarbiavimo santykius su ikimokyklinio ugdymo istaiga, gal norètu didesnès iniciatyvos iš pedagogu pusès?

Informantų vertinimu, jų, kaip tėvų iniciatyvos pakanka . „...manau, kad rodau, gal kartais net per daug. Bet tikiu, kad šiai dienai iniciatyvu pakanka“, “... visaip būna, bet dažniausiai aš". Jie norètų daugiau iniciatyvos iš pedagogų. ,....̌̌inoma, būtu gerai, jei ir iš pedagogu pusès būtu daugiau iniciatyvos, tarkim, paskutini mènesio penktadieni pedagogas skambučiu, el. laišku ar tiesiog gyvai susitikus, suteikia visa informacija apie vaiko pasiekimus ar ugdymo spragas". Pedagogai ir tèvai neturètų laukti, kol viena ar kita ugdymo dalyvių grupé žengs pirmą žingsnį, bet patys ji žengtų: eitų bendravimo link, ieškotų kontakto. Gauti tyrimo rezultatai leidžia teigti, kad ikimokyklinio ugdymo ịstaiga turètų eiti nuo abipusio atvirumo ir keitimosi informacija santykio link dialogu grịstos partnerystès su mokytojais ir tèvais.

\section{Išvados}

1. Teoriniame lygmenyje tėvų ir mokytojų bendradarbiavimas, grịstas abipuse partneryste yra reikalingas ir reikšmingas vaikui su specialiaisiais ugdymosi poreikiais, kuris aprépia suinteresuotus ugdymo dalyvius, galinčius nulemti ugdymo proceso sèkmingumą. Šiandien ikimokyklinio ugdymo įstaigoslabiau turètų eiti nuo abipusio atvirumo ir keitimosi informacija santykio link dialogu grịstos partnerystès su tèvais, o tèvai taip pat siektų su mokytojais geranoriškai derinti savo požiūrius ị specialiųjų ugdymosi poreikių vaiko ugdymą, tartųsi dèl jo poreikių tenkinimo formų ( diskusijų, praktinių pavyzdžių pateikimo, dalyvavimo ugdomosiose veiklose ir kt.), būdų ugdytinio gerovès labui. Partnerystė - ugdymo dalyviai (tėvai, mokytojai, švietimo pagalbos specialistai ir kt.) yra atviri vieni kitiems, geranoriškai derina savo požiūrius siekant kokybiško specialiujų ugdymosi poreikių vaiko ugdymo bei pagalbos. Geras bendravimas ir tarpusavio ryšys yra esminis tikros partnerystès bruožas.

2. Specialiụjų ugdymosi poreikių vaikų tėvų požiūriu, poreikis pedagoginiam švietimui siekiant partnerystès yra aktualus, tačiau labai dažnai jis suprantamas kaip tradicinis informavimas apie specialiųjų ugdymosi poreikių vaiką, jo galias ir sunkumus, o ne bendrų veiklų organizavimas, grịstas dialogiškumu ir refleksija. Visiems tèvams priimtiniausios pedagoginio švietimo formos yra individualūs pokalbiai su švietimo pagalbos specialistais (specialiuoju pedagogu, logopedu) ir ju konsultacijos. Galima teigti, jog vyksta nuolatinė tėvų komunikacija su pedagogais, tačiau jiems labai trūksta nuoseklesnès informacijos apie vaiko pasiekimus, vaiko savijautą, praktinių patarimų. Dažiausiai taikomos pedagoginio švietimo formos - individualūs pokalbiai, konsultacijos, kurios padeda suprasti bei atpažinti specialiųjų ugdymosi poreikio vaikų galias ir ugdymosi sunkumus. 
Poreikis bendradarbiauti, kuris būtų paremtas partneryste yra didžiulis, tačiau tèvai pageidautų iš pedagogų daugiau iniciatyvos. Tik intensyvus bendradarbiavimas ir partnerystė su mokytojais gali užtikrinti kokybišką specialiujų ugdymosi poreikių vaikų ugdymą.

\section{Literatūra}

1. Burvytė, S. (2013). Šeimos ir ikimokyklinių ugdymo institucijų bendradarbiavimas: pozityvios tèvystès skatinimo aspektas. Socialinis ugdymas, nr. 3, Vol. 35. P. $122-136$.

2. Braslauskienè, R., Jonutytè, I. (2005). Vaikų agresyvaus elgesio prevencija ugdymo instuticijose. Klaipėda: Klaipėdos universiteto leidykla.

3. Gelžinytė, I., Bagdonas, A. (2016). Šeimų, auginančių 4-5 vaikus, dalyvavimas ugdomojoje veikloje. Tarptautinè mokslinė konferencija. Ikimokyklinio ir priešmokyklinio ugdymo pedagogu rengimo problematika, p. 70-75.

4. Gustaitienè, I., Širiakovienė, A. (2020). Priešmokyklinio ugdymo pedagogų ir tėvų bendravimas ir bendradrabiavimas (Kauno miesto atvejis). Jaunųjų mokslininkų darbai, nr. 50 (1). P. 6-13.

5. Kovienè, S. (2017). Tèvų švietimas ikimokyklinèse ugdymo įstaigose: lūkesčiai ir realybė. Andragogika, nr. 1 (8). P. 147-158.

6. Kovienè, S. (2017). Tèvų įsitraukimas ị ikimokyklinès ugdymo įstaigos veiklą: tèvų nuomonè. Švietimas, politika, vadyba, nr. 9 (2), p. 76-88.

7. Leliūgienè, I., Simanavičiūtè, I. (2010). Pedagoginis tėvų švietimas kaip sèkmingos vaikų socializacijos prielaida. Socialinis darbas, nr. 9 ,(1). P. 114-121.

8. Mahmood, S. (2013). First-Year Preschool and Kindergarten Teachers: challenges of working with parents. School community journal Vol. 23, no. 2, 55-60.

9. Martišauskienè, D. (2008). Pedagogų ir tèvų nuostatos ị ikimokyklinio ugdymo tikslus, formas, metodus (atvejo analizè). Jaunųjų mokslininkų darbai, nr. 4 (20), p.186-191.

10. Martišauskienè, D., Trakšelys, K. (2017). Švietimo paslaugų kokybės valdymo vertinimas. Tėvų požiūris. Tiltai, nr. 2, p.103-118.

11. Nihat, S.S., Oguz, G. (2013). Primary school students'parents' level of involvement into their children's education. Educational sciences: theory and practice, Vol. 13, no.2, $1006-1011$.

12. Pretis, M. (2011). Meeting the needs of parents in early childhood intervention: the educational partnership with parents - good practice and challenges. Journal of policy and practice in intellectual disabilities. Vol. no.2, 73-76.

13. Šilenienè, B., Širiakovienè, A. (2018). Pradinių klasių mokytojų ir mokinių tėvų požiūris i tarpusavio bendradarbiavimą. Švietimas, politika, kokybė., nr.1, vol. 10, p.8-25.

14. Trakšelys, K. (2010). Tẻvų įtraukimas ị aplinkos pedagogizavimą taikant andragogines sistemas. Socialinių mokslų studijos, 4 (8), p. 57-68.

15. Valantinas, A. (2015). Kaip bendradarbiauti su tèvais ir kitais ugdytojais siekiant vaiko ugdymosi pažangos. Ikimokyklinio ugdymo metodinès rekomendacijos, p.2-4. (žiūrèta 2021, rugsėjo24d.) Prieiga per internetą: https://www.ikimokyklinis.lt/uploads/files/dir1049/dir52/dir2/17_0php.

16. Valantinas, A., Čiuladienè, G. (2013). Tèvų ịsitraukimo ì mokyklos gyvenimą, mokymosi pasiekimų ir mokytojo darbo vertinimo sąsajos. Socialinis darbas, nr. 12 (2), p. 308-318.

\section{EDUCATIONAL FOR PARENTS WITH PRESCHOOL CHILDREN WITH SPECIAL EDUCATIONAL NEEDS AIMING AT WORKING IN PARTNERSHIP WITH EDUCATORS}

Jūratė Klizaitė, Aniuta Varneckienė, Aurelija Valaitienė

\section{Summary}

Recently, more and more general education institutions are attended by children with special educational needs. This obliges both the educational institution and the parents to become two institutions that constantly interact and complement each other, allowing the successful implementation of educational goals. Today, educational institutions should move more from the relationship of mutual openness and exchange of information to a dialogue-based partnership with parents, and parents should also seek to combine their views on the child's education with educators benevolently, to discuss ways and 
means of meeting their needs. Partnership - educational participants (parents, educators) are open to each other, benevolently coordinate their approaches to the education of a child with special educational needs, consult on educational goals, ways to meet his needs. A number of problematic aspects emerge by delving into the topicalities of pedagogical education of parents raising children with special educational needs to achieve dialogue-based cooperation. There is a tendency that educators working with children with special educational needs do not always focus on their parents as partners, do not apply significant forms of cooperation to this group, at the same time reduce parental participation in the educational process, opportunities for cooperation and its effectiveness. Traditional forms of informing parents prevail: joint meetings, individual conversations with the group educator, and information is provided on the notice board. Educators working with children with special educational needs do not always focus on their parents as partners, sometimes offering only insignificant areas of collaboration, thus narrowing parental involvement, collaboration opportunities, and its effectiveness. Parents and educators usually communicate during conversations when they bring or pick up children.

The problem of the research: How is going the pedagogical education of parents raising preschool children with special educational needs in partnership with educators?

The object of the research is pedagogical education of parents in order to achieve a partnership with educators.

The aim of the research is to analyse the pedagogical education of parents raising preschool children with special educational needs in order to achieve a partnership with educators.

\section{Research tasks:}

1. To reveal the pedagogical education of parents raising preschool children with special educational needs by means of theoretical analysis in order to achieve a partnership with educators.

2. To investigate the attitude of parents of children with special educational needs of preschool age to pedagogical education by means of an interview analysis.

Research methods: 1) analysis of scientific literature, 2) oral survey using a semi-structured interview. Data were processed using qualitative content analysis.

From the point of view of parents who raise children with special educational needs, the need for pedagogical education for partnership is relevant, but it is often understood as their traditional information about the child's education, rather than the organization of joint activities based on dialogue and reflection. The most acceptable forms of pedagogical education for all parents are individual conversations with educational support specialists and their consultations. It can be stated that there is constant communication of parents with educators, but they are still lacking in more consistent information about the child's achievements, the child's well-being, practical advices. The most commonly used forms of pedagogical education are individual conversations, consultations, and positive parenting groups, which help to understand, recognize and correct a child's misbehaviour. The need for cooperation based on partnership is vast, but parents would like more initiative from educators. Only intensive cooperation and partnership with educators can ensure the quality education of a childs with special educational needs.

Keywords: children with special educational needs, family, pedagogical education of parents, partnership. 